\title{
Specify SDH Complex Mutation
}

National Cancer Institute

\section{Source}

National Cancer Institute. Specify SDH Complex Mutation. NCI Thesaurus. Code

C160582.

A request to enter the specific SDH complex mutations that were identified in the study. 